\title{
Collaborative development: Capturing the public value in private real estate development projects in Ho Chi Minh City, Vietnam
}

Article · June 2017

DOI: 10.1016/j.cities.2017.06.006

CITATIONS

0

4 authors, including:

Thanh Bao Nguyen

Radboud University

5 PUBLICATIONS 8 CITATIONS

SEE PROFILE

\section{James H Spencer}

Clemson University

57 PUBLICATIONS 266 CITATIONS

SEE PROFILE
READS

133

\section{Erwin Van der Krabben \\ Radboud University \\ 78 PUBLICATIONS 417 CITATIONS \\ SEE PROFILE}




\title{
Collaborative development: Capturing the public value in private real estate development projects in Ho Chi Minh City, Vietnam
}

\author{
Thanh Bao Nguyen ${ }^{\mathrm{a}, \mathrm{b}, *}$, Erwin van der Krabben ${ }^{\mathrm{a}, \mathrm{f}}$, James H. Spencer ${ }^{\mathrm{c}, \mathrm{e}}$, Kien T. Truong ${ }^{\mathrm{d}}$ \\ a Institute of Management Research, Radboud University, Nijmegen, Netherlands \\ b Faculty of Civil Engineering and Architecture, Ho Chi Minh City Open University, Viet Nam \\ ${ }^{\mathrm{c}}$ Department of City Planning \& Real Estate Development, Clemson University, Clemson, USA \\ d Urban Division, Ho Chi Minh City People's Council, Ho Chi Minh City, Viet Nam \\ e Environmental Change, Vulnerability and Governance Program, The East West Center, HI, United States \\ ${ }^{\mathrm{f}}$ School of the Built Environment, University of Ulster, Northern Ireland, United Kingdom
}

\section{A R T I C L E I N F O}

\section{Keywords:}

Value capture

High-rise buildings

Ho Chi Minh City

Urban redevelopment

\begin{abstract}
A B S T R A C T
This article addresses a relative gap in the literature on real estate development and property rights in transitional economies, particularly on the "shadow" role of private developers in urban management at the local level. The paper argues that the development of high-rise buildings in Vietnam resulted from the national privatization policy shift known as Doi Moi that gave landowners greater rights. These changes in land rights policy are important constitutive elements for institutional functionality of value capture via privatization of land, to become viable and effective. Further, the paper describes how private developers (foreign and domestic) take advantage of vague and indistinct city governance regarding privatization of land, while the property rights of the original users of the land are insufficiently protected. These issues are illuminated and analyzed through the use of three case studies of commercial projects in Ho Chi Minh City. We suggest a further institutionalization of privatization of land and value capture in Vietnam.
\end{abstract}

\section{Increasing land values and value capture}

International development institutions like the United Nations (1976) and the World Bank (2015a) have long recognized and stressed the importance of urban land policy and land rights in the development process. One of the most important functions that improved policy and rights in development plays is rationalizing the value capture of land use and land appreciation, which is often generated by actions from those other than the landowners; namely, public investments in infrastructure. This question of value capture has tremendous importance for the sustainability and viability of the communities that host large development projects. As a transitional country, Vietnam's main value capture strategy is based on the privatization of land (Section 3). However, the insufficient institutionalization of this system and the absence of clear guidelines may threaten sustainable urban growth in rapidly expanding cities like Ho Chi Minh City.

Rapidly increasing commercial activities resulting from urbanization have generated a high rate of consumption of city-center urban land. Since the supply of urban land is limited, most of this urban central growth has taken place through the conversion of land from residential into commercial use. Because of their unique locations, urban-center lands often are subject to problems regarding the control of building development, inefficient land use, extreme land speculation, and high land prices (Son, 2013; Temelová \& Dvořáková, 2012; Zeković, Vujošević, \& Maričić, 2015).

This article addresses privatization of land and value capture in Vietnam, by focusing particularly on the Central Business District of Ho Chi Minh City (HCMC), Vietnam, and its micro-planning of the redevelopment of the urban center. It examines a new flexible-urban management mode that has emerged in Vietnam, and contrasts significantly with Vietnam's central planning system of the pre-Doi Moi days. We also question how the public sector and private developers negotiate privatization and development of land based on long-term leasehold, to illustrate the critical importance of value capture in a transitional urban setting. We believe that the research presented in the article is also relevant for an international audience. The Vietnamese experiences with a transitional land market can be linked to similar processes in some other countries and particularly in China, while the difficulties HCMC faces with implementing an efficient and fair value capture mechanism in a context of underdeveloped regulatory

\footnotetext{
* Corresponding author at: HCMC Open University, Faculty of Civil Engineering and Architecture, Ho Chi Minh City, Viet Nam.

E-mail addresses: thanh.nb@ou.edu.vn (T.B. Nguyen), e.vanderkrabben@fm.ru.nl (E. van der Krabben), jhspenc@clemson.edu (J.H. Spencer), kientruong05@gmail.com (K.T. Truong).
} 


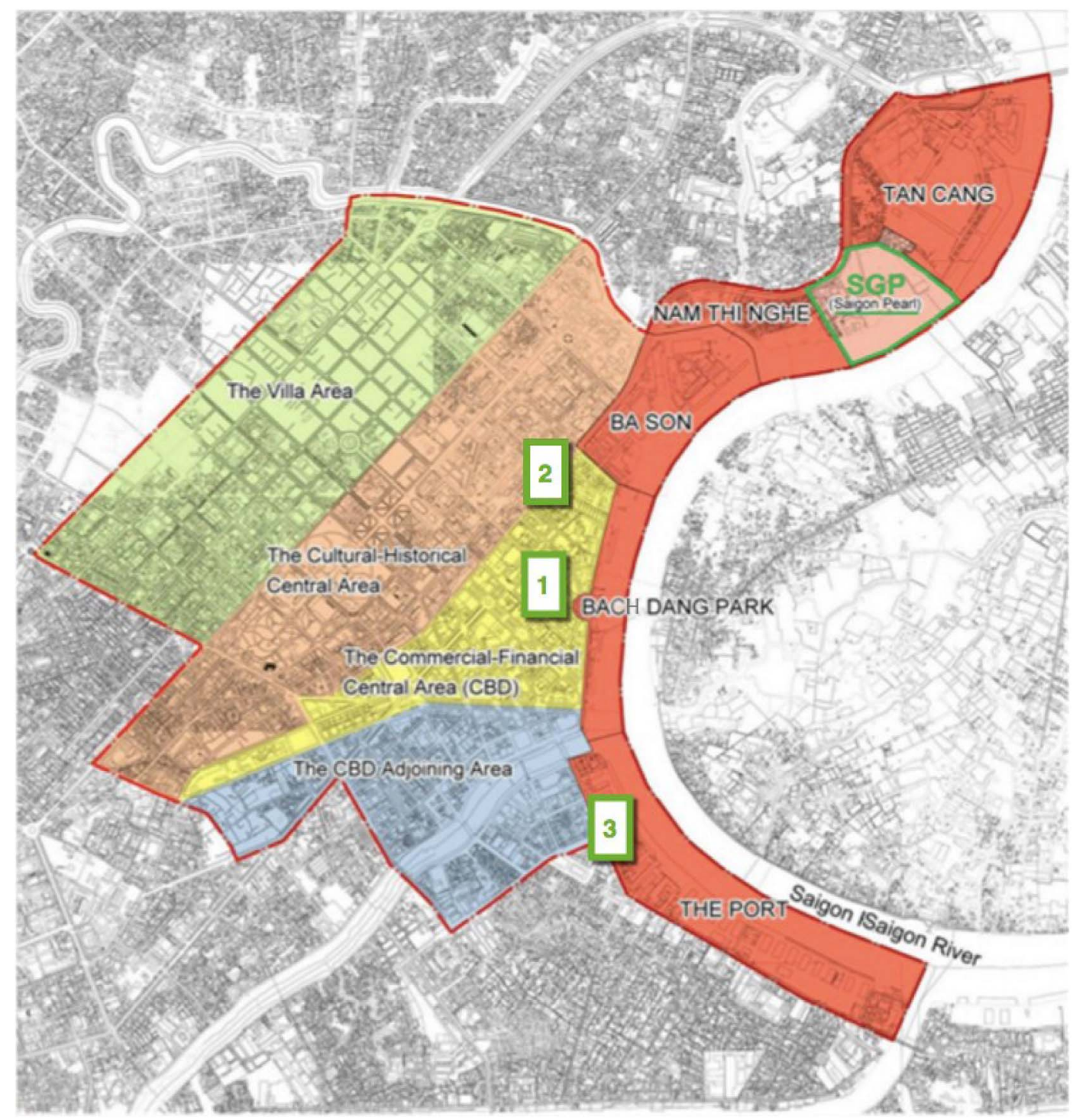

Fig. 1. Location of three buildings in HCMC Central Area: 1. Times Square; 2. The Lancaster and 3. REE 2 Tower Project.

institutions can be found in many other developing countries as well.

We explore these issues in Vietnam by presenting three cases of high-rise building development in the central area of Ho Chi Minh City built in the late 1990s and early 2000s (See Fig. 1). The case studies may be seen as narratives that illustrate how underdeveloped regulatory institutions and a nascent but fast-growing private real estate sector are at odds in Vietnam.

\section{Methodology}

This paper is based on a combination of literature review and empirical data. The empirical research is largely based on information gathered from May to October 2012, from June to August 2013, and from July to September 2015 in Ho Chi Minh City. The main activities included an extensive field reconnaissance survey, classified document searches and interviews with key informants. Information on earlier construction and discussions of changes in investment relied on interviews with staff members of the Ho Chi Minh City Department of Planning and Architecture (DPA) and Department of Construction (DoC), two realtors, four developers and two former residents.

Primary data collection was carried out at three commercial projects in HCMC's District 1 - Times Square, The Lancaster and REE 2 Tower Project (See Fig. 2). Secondary data and information were also collected, consisting of government records of city-level and regulations on center area management. For governance in spatial center areas, in addition to secondary data, we carried out unstructured interviews with key informants who work in the center management unit of the DPA. Finally, potential alternatives to present value capture practice in HCMC were discussed with several local experts, both from academia and the public sector.

The paper is organized into seven sections. Section 2 discusses Vietnam's changing planning system and property rights regime. Section 3 provides a brief literature review of value capture tools and discusses value capture mechanisms in Vietnam. Section 4 briefly describes high-rise development in HCMC. In Section 5, the results of three case studies of high-rise development in HCMC, including negotiations between public sector and private developers and value capture practice are presented. Section 6 aims to critically evaluate these cases and suggests possible needed adjustments to current policy and planning. Finally, Section 7 concludes the discussion and raises some issues for further debate and research.

\section{Institutional context: the Vietnamese planning system and property rights regime}

The post-1975 housing situation in Vietnam created a number of 


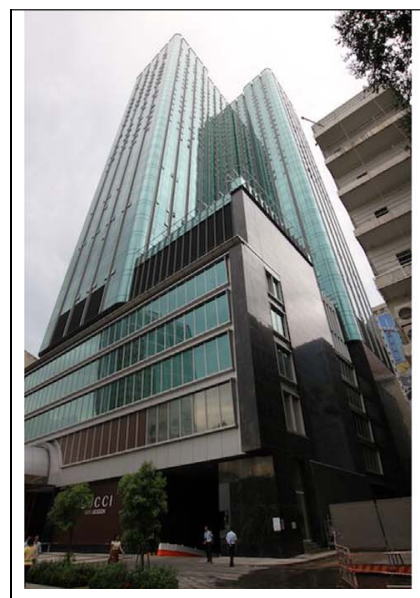

1. Times Square

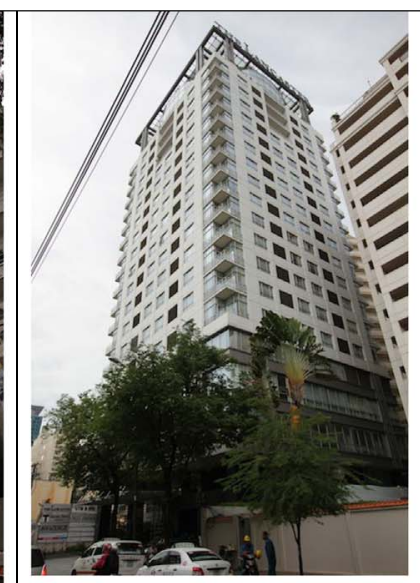

2. The Lancaster

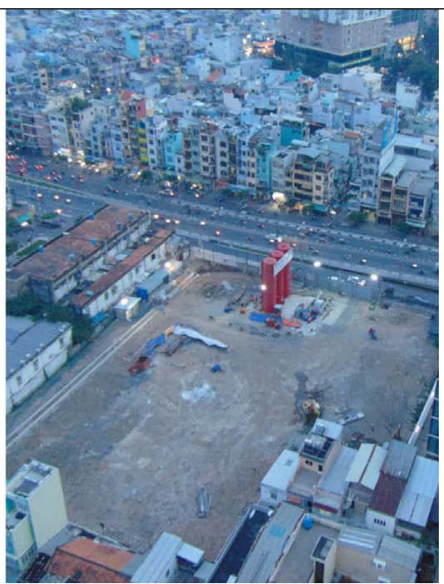

3. REE Tower 2 (under construction in 2016)

Fig. 2. Three case studies.

Source: Field Survey, 2016.

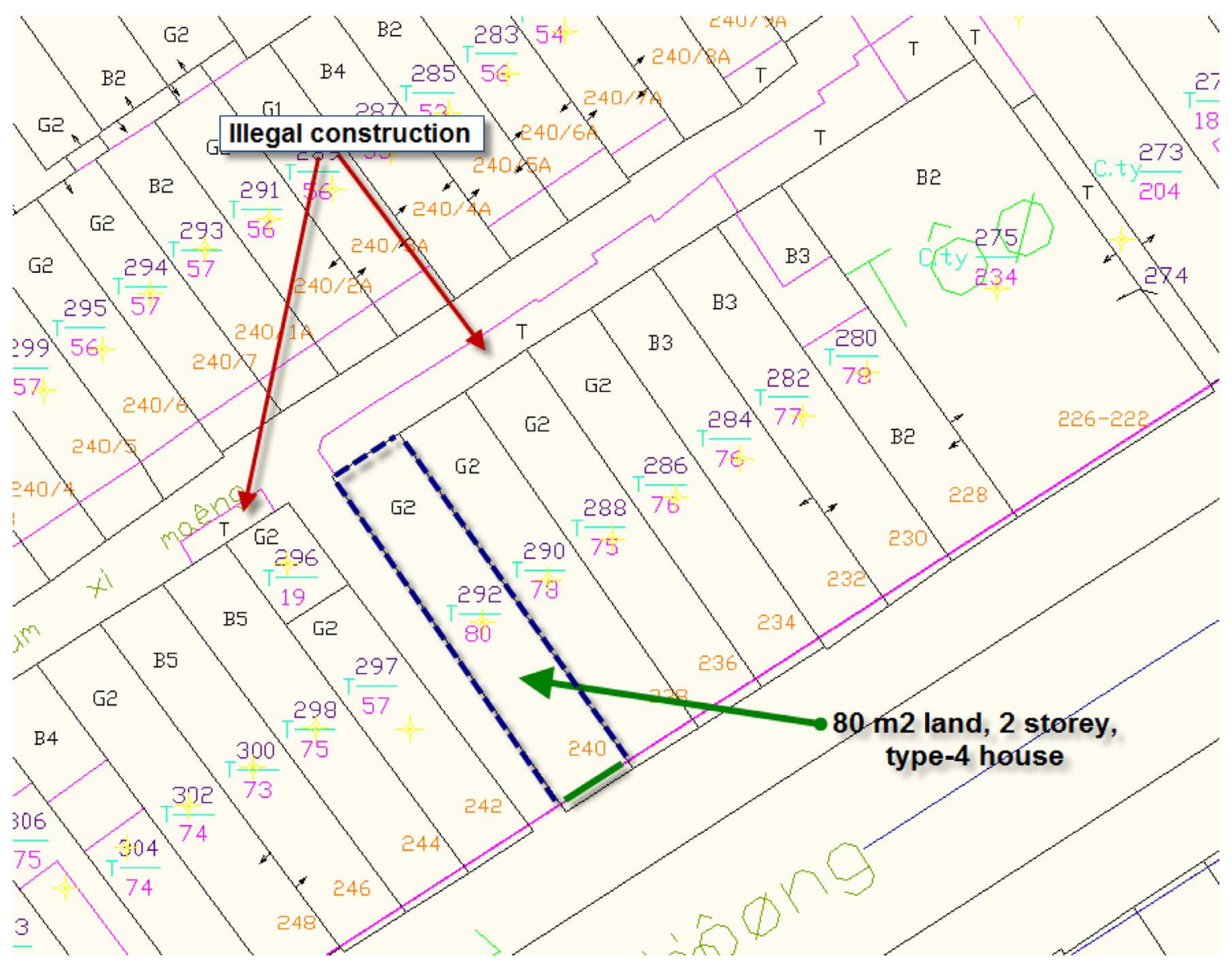

Fig. 3. Typical illegal constructions (pink boundary).

Source: DPA, 2011.

challenges for planners. For about 20 years following the end of the war with the United States, residents of Ho Chi Minh City tended to upgrade their houses without any official permission from local authorities. This activity led to hundreds of thousands of upgraded units across the city that had never been permitted (Scarpaci, 2000). In the context of a wardamaged city, the scale of this lack of permission and documentation was particularly extensive. To date, some illegal buildings have been legalized ex post facto, since excessive construction often happened by expanding beyond a legal boundary into a common area (see Fig. 3). This common phenomenon across rapidly developing cities has generally come about due to an evolving culture and practice of urban planning, as well as the increasing emphasis of the state on local policy making.

\subsection{Gradual change in the planning system: 1975-1992}

Before 1986, planning procedures in Vietnam required extensive procedural preparations regarding the implementation of a new development project. Given the high cost and the long time needed for the preparation of general plans, there were practically no resources left to 

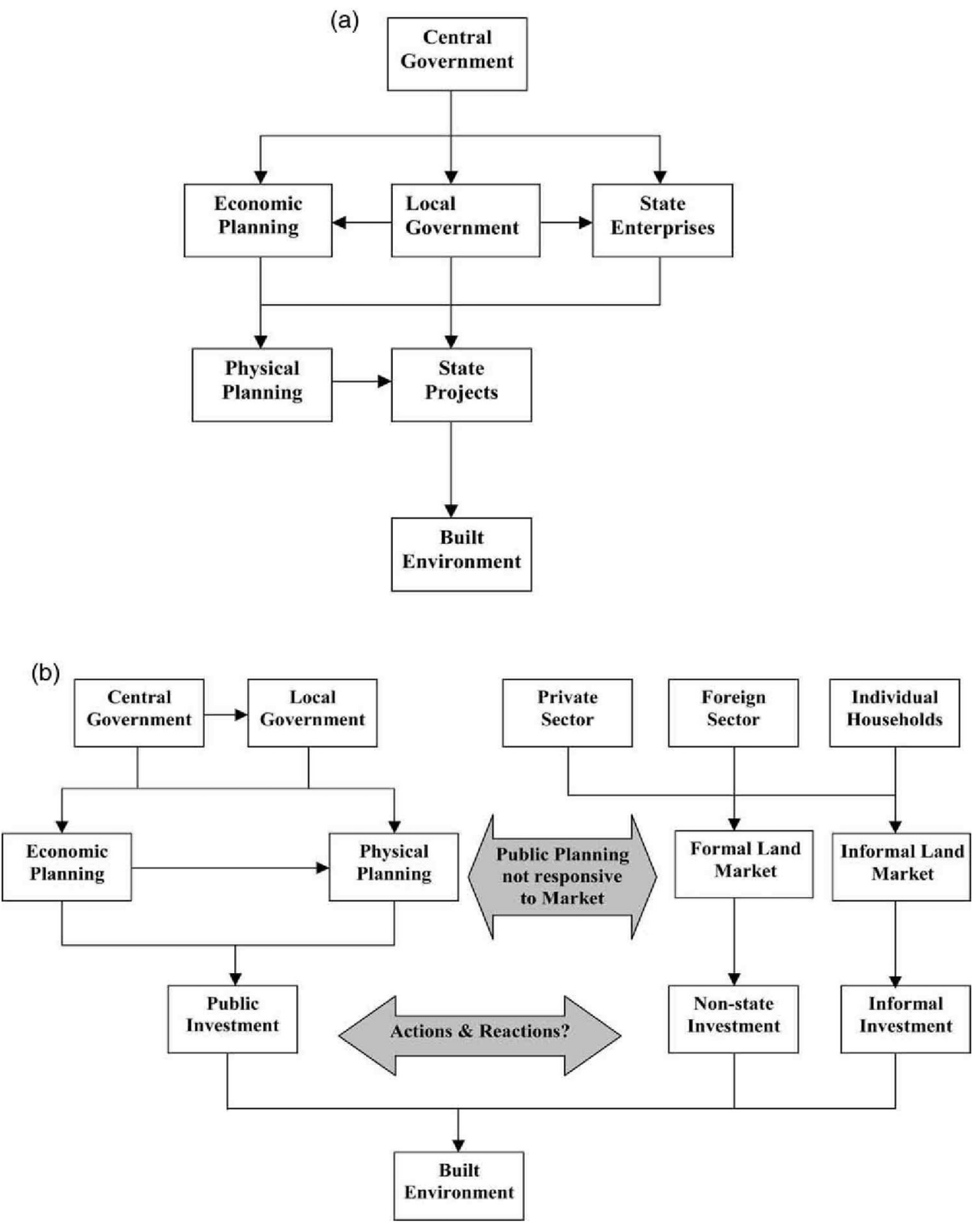

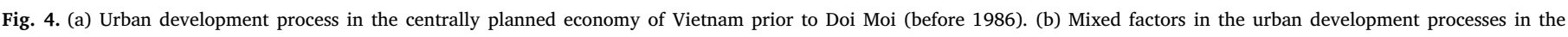
transitional economy of Vietnam since 1986.

complete detailed plans in many urban areas. Because the general plans were more convenient in outlying, greenfield areas, urban planning often paid attention to new built-up areas, at the expense of old city cores, a practice that resulted in the dilapidation of older settlements. As private development was not recognized in the investment planning, neither land nor detailed plans were foreseen for privately built activities. HCMC was no different from other parts of Vietnam, and according to Huynh (2015) there was essentially no practical urban planning in HCMC at all in the de-urbanization period after 1975. During that period, city planners played an active role in the selection of factory sites, the functional division of urban land use, and the design of residential areas. In reality, urban planning often resulted in abstract plans without any mechanisms for implementation.

After 1986, and especially in 1992, the administration enacted Decree 91 to improve program implementation under the terms of a multi-sector market economy (See Fig. 4). A previous, five-stage planning style was replaced by a shorter process containing only two types of plans (master and detailed plans). Master plans are prepared for feasibility over a 20-year timeline, with updates every five years. Detailed plans are drawn up according to the master plan and prepared at a scale of 1:500 to 1:2000 for specific areas. In this new urban planning process, market-led factors are recognized such as private land use 
rights, individual commercial activities along the streets, and zones for foreign capital investment. Additionally, a regulatory document is attached to the land use plans to guide construction management. Nonetheless, although the new law included some innovations, planning and management remained similar to the past model, in that it was difficult to implement effectively. In part, this difficulty was the result of unclear property rights.

\subsection{Vietnam property rights regime}

In countries transitioning from a socialist system to a market-based one, property rights are the most essential institutional arrangements that create the framework for a market-based economy. In considering the functions of property and land rights, it is important to place these rights in the context of the overall institutional structure within the society and economy (Feder \& Feeny, 1991). Most notably, since the introduction of Vietnam's first Land Law in 1993, consecutive new versions of this law have led to almost full privatization of property and land rights, although the present 2013 Land Law does still not allow full ownership over land (see Appendix A). The situation in Vietnam resembles to a certain extent the present state of the land market in China, where land is also state-owned and a state-dominated market in longleasehold rights over land has developed (Ding, 2007, 2013; Ho, 2017; Lai, Peng, Li, \& Lin, 2014; Perkins, 2009; Shan, Yu, \& Wu, 2017; Sun \& Liu, 2016). While selling these long-leasehold rights over land has become a major source of income for Chinese cities, compensating for an unbalanced tax system that provides them with insufficient budgets, the land finance model also jeopardizes China's sustainable development because it encourages city governments to sell much more land than is needed (Zheng, Wang, \& Cao, 2014). Similar problems seem to be found in Vietnam (Thien Thu \& Perera, 2011), where cities lack a local tax base as well (McCluskey \& Trinh, 2013) and proper value capture mechanisms to finance public infrastructure are missing.

International institutions have already advocated for a long time value capture as a land policy tool and source of income for cities in developing countries (Sharan, 2016; Smolka, 2013b; UN-Habitat, 2015; Walters, 2012; World Bank, 2015b), but in many of these countries value capture still has not been institutionalized. Present approaches to value capturing in Vietnam - the topic of this paper - are the result of continuous changes that took place with respect to the property rights regime in the period of transition. Although a full analysis of these changes falls outside the scope of this paper, Table 1 does present an overview of relevant studies of (transitions in) the property rights regime in Vietnam, covering Vietnam's 30-year-long period of development and change under the socialist market economy. In the analysis of value capturing mechanisms in this paper we will refer to (changes in) the property rights regime when relevant.

\section{Value capture}

\subsection{Types of value capture}

Value capture refers to the process by which all, or a portion of, increments in land value attributed to "community-level interventions" - often taking the form of improved infrastructure - rather than landowner actions, are recouped by the public sector and used for public purposes. These "unearned increments" may be captured indirectly through their conversion into public revenues as taxes, fees, exactions or other fiscal means, or directly through on-site improvements to benefit the broader community (Alterman, 2011). In principle, there is a connection between spatial planning and land value because any improvements to neighborhoods, local infrastructure and services are reflected in appreciating value to any of the land affected by these changes. Additionally, since central cities have the greatest number of factors likely to affect neighborhood-scale characteristics, the number of potentially influencing factors is the highest, and the magnitude of investment is highest on a per-square-foot basis. Thus, securing even a small share of the increase in central city property values is a significant asset that goes to raise the value to the individual landowner (private or corporate) and to the local government in helping to pay for reinvestment in local infrastructure.

The international value capture literature continues to discuss various aspects of value capture, most notably: (1) the rationale behind value (Alterman, 2011; Rodríguez-Bachiller, Thomas, \& Walker, 1992); (2) the effectiveness of tools and mechanisms for value capturing (Huxley, 2009; Smolka, 2013b; Smolka \& Amborski, 2000; Tira, Van der Krabben, \& Zanon, 2011; Van der Krabben \& Needham, 2008; Walters, 2012); (3) how much value can be captured (Cervero, 1994; Smith \& Gihring, 2006); and (4) the institutionalization of value capture in planning regulation and land law (Alexander, 2012). Alterman (2011) distinguishes three important sets of policies that influence value capture: (1) macro-economic policy, (2) direct regulation, and (3) indirect instruments. Macro policy includes substitution of private property by long-term public leaseholds, land banking, and land readjustment. It also comprises nationalization or privatization of all land under long-term use rights and transferability, something many former socialist countries have done. Land readjustment is an advanced device that can be deployed as a macro instrument (Van der Krabben \& Needham, 2008). Direct regulation covers taxes on land or increment taxes upon transfer title and raises an annual property tax or capital gains tax on property. And indirect instruments for value capture are exactions, cost recovery, or infrastructure-based betterment capture and developmentrights based betterment.

Value capture instruments that charge for building rights - also referred to as exactions - have provided partial or full funding for major urban redevelopment projects in many cities (Smolka, 2013a). Charges for being allowed additional building rights are based on the separation of building rights from land ownership rights, which allows the public to recover the land value increment resulting from development rights over and above an established baseline. Exactions are fees aimed to force the developer to pay for a suitable share of the infrastructure that assists the public development under discussion (Evans-Cowley, 2008). For example, in-kind contributions of facilities built by the developer and given to the city are exactions. Other examples can be found where the state requires the land sub divider to allocate a certain percentage of the area for affordable housing (Darosa, 2007), referred to as inclusionary housing in some localities (Calavita \& Mallach, 2009).

Indirect value capture through exaction fees is perhaps the most effective form of value capture, flexible enough to adapt to differing institutional contexts and regulatory environments. Overall, a relatively large amount of literature in developed countries on value capture in urban land redevelopment provides a number of alternatives for urban planners and managers, but the lack of studies on this topic in developing countries makes it difficult to develop policy reforms for urban value capture with any level of confidence.

\subsection{Value capture in Vietnam}

Value capture in Vietnam primarily relates to the 'privatization' of land. As a form of land banking, public authorities clear land by compensating the existing users, either voluntarily or by expropriation (the users hold long-term user rights, but the land is still owned by the state) and then sell long-term leasehold rights over the land against full commercial market value to a private developer. Though the land is not fully privatized - the private developer does not receive full ownership over the land, but a long-term leasehold right - the city authorities nevertheless generate income by trading the user right that can be used for infrastructure provision or any other purpose. This practice is an example of what Gerber, Nahrath, and Hartmann (2017) call "the strategic use of time-limited property rights," and is a convenient way for the state to maintain some limited control over land use - seemingly an extremely important power under conditions of rapid change. While their cases from Switzerland are from a very different political and 
Table 1

Summary: Results of urban and property rights development studies in Vietnam during the transition period.

\begin{tabular}{|c|c|c|c|}
\hline & Post socialist planned economy & Transitional economy & Socialist market economy \\
\hline & Phase I: $1986-1991$ & Phase II: 1992-2002 & Phase III: 2003-2013 \\
\hline Background & $\begin{array}{l}\text { 1. Centralization of decision making } \\
\text { emerging of local developmental state } \\
\text { (Fforde, 2010). } \\
\text { 2. Government located housing with very } \\
\text { low rent price (Quang \& Kammeier, 2002) }\end{array}$ & $\begin{array}{l}\text { 1. Urban reforms recognized legal transfer of land use } \\
\text { rights (Hare, 2008). } \\
2 \text {. The local government's tight budget is inadequate } \\
\text { for the ambitious urban redevelopment } \\
\text { (McCluskey \& Trinh, 2013). }\end{array}$ & $\begin{array}{l}\text { Under the coalition, it was found: } \\
\text { 1. Uncertainty of redevelopment flexible planning } \\
\text { control (Xuan et al., 2012) } \\
\text { 2. Issues of housing for low income people (Waibel, } \\
\text { Eckert, Bose, \& Martin, 2007) }\end{array}$ \\
\hline $\begin{array}{c}\text { Property rights } \\
\text { evolution }\end{array}$ & $\begin{array}{l}\text { No laws regulating the use and ownership } \\
\text { of property (Gillespiet, 1998). }\end{array}$ & $\begin{array}{l}\text { Introduction of the first land laws with prime concept } \\
\text { of ownership, resulting in widespread speculation and } \\
\text { soaring prices (Thien Thu \& Perera, 2011). }\end{array}$ & $\begin{array}{l}\text { Property rights over land for real estate development } \\
\text { now clearer defined (Zhu, 2011). } \\
\text { Occurrence of 'tragedies of the anticommons' and } \\
\text { owners' strategies to deal with them (Nguyen, Van der } \\
\text { Krabben, \& Samsura, 2016) }\end{array}$ \\
\hline Physical result & Little redevelopment in CBD & $\begin{array}{l}\text { Rapid large scale urban redevelopment with negative } \\
\text { externalities (McPherson, 2012) } \\
\text { Gentrification, as the result of the emergence of a new } \\
\text { middle class (Vinh \& Leaf, 1996) }\end{array}$ & $\begin{array}{l}\text { Rush of foreign developers to Ho Chi Minh City and } \\
\text { Hanoi Capital, led to numerous new commercial and } \\
\text { luxury developments (Huynh, 2014) }\end{array}$ \\
\hline Institutional result & $\begin{array}{l}\text { 1. Centrally planned housing system - } \\
\text { distribution by the State (Phe, 2002) } \\
\text { 2. Increased housing demand }\end{array}$ & 1.Resident's socialist land use rights phase out & $\begin{array}{l}\text { 1. Introduction of new land law in } 2013 \\
\text { 2. Increased foreign investment, increasing incomes } \\
\text { and emerging mortgage market.(Tan, 2010) }\end{array}$ \\
\hline Real Estate Market & $\begin{array}{l}\text { Non-existent formal real estate market } \\
\text { (Kim, 2004) }\end{array}$ & $\begin{array}{l}\text { Many failed foreign projects due to the Asian financial } \\
\text { crisis (Dapice et al., 2009). }\end{array}$ & $\begin{array}{l}\text { Condominiums and mix-use office-commercial } \\
\text { developments replace traditional shop houses } \\
\text { (Huong \& Sajor, 2010) } \\
\text { 'Divided' commercial real estate market foreign and } \\
\text { domestic investors (Nguyen, van der } \\
\text { Krabben, \& Samsura, 2014) }\end{array}$ \\
\hline
\end{tabular}

economic context, the importance of blurred lines between the public and private rights to land is common to the state's ability to do long term land use planning both in the Global North and South. Although not the same as private ownership in an absolute sense, we call this granting of rights "privatization" because it shifts land use rights closer to the private end of a spectrum. In Vietnam, two main privatization strategies are used. The first strategy concerns the direct sale of longterm leasehold rights over land to a private developer. The city authorities are free to decide how to use the income. The second strategy is referred to as the Land-for-Infrastructure mechanism (Labbé \& Musil, 2014): as an in-kind payment for the construction of new public infrastructure, the developer receives leasehold rights over a piece of land that will be allocated for a certain urban use category (residential, commercial). In both strategies, the city authorities must facilitate the process by clearing the land. To clear the land of residents, local authorities must buy them out or expropriate their land to allow the transformation of the location into its new use.

While in some European countries (Switzerland, the Netherlands), the strategic use of long-term leasehold over land ('ground leases') has contributed to increased flexibility in and effectiveness of land-use planning (Gerber et al., 2017), the opposite seems to be true in countries like China and Vietnam, where all land is state-owned. Though the privatization strategies are rather effective in capitalizing and capturing all increment value as the result of assigning an urban use category to a certain area, the system as it is applied in Vietnam has been criticized for several reasons. First, social issues appear. Labbé and Musil (2014) criticize the system that defines compensations paid to the original users. In the early 1990s Vietnam introduced a land valuation mechanism known as the 'Land Pricing Framework' (LPF): 'this is a statestipulated price chart used to determine the compensations to which households are entitled when the lands on which they have use-rights are expropriated for redevelopment' (Labbé and Musil, p. 7). In practice the 'set' compensation values for lands create a significant rent gap with the 'market' values for lands. Thien Thu and Perera (2011) have referred to this as 'dual-price-system'. The rent gap - purposefully institutionalized by the state - 'creates, in practice, a large reserve of cheap, periurban land which can easily be expropriated and redeveloped when investment opportunities arise' (Labbé and Musil, p. 7).
Second, the Land-for-Infrastructure mechanism has fuelled urbanization at the periphery of Vietnamese cities, often resulting in urban sprawl and poor-quality urban areas with insufficient and uncoordinated public infrastructure. Labbé and Musil (2014) argue: '(a) common problem is that developers prioritize the construction of commodity housing, commercial buildings and office space at the expense of the non-marketable, public components in projects. In some cases, the construction of public amenities is delayed by several years. In others, developers modify approved plans and use areas originally earmarked for public amenities for the construction of commodity housing and commercial buildings'.

Third, Huynh (2015) states that these privatization strategies open the way for negotiations between city authorities and private developers, in the absence of a clearly institutionalized system. In practice, the influence of private developers has caused frequent changes to be made to plans. Huynh (p. 16) claims: '(i)t is hard to deny the influence of private developers in shaping the urban planning in HCMC. The process of city building has in reality been determined by real estate developers (some say speculators)'. Only recently, according to Huynh (2015), has the municipal government officially acknowledged the influence of developers on the city's urban planning and expressed concern about the negative impacts of such influence.

Finally, above we referred to similar practices in China, where cities' reliance on income from land sales leads to unsustainable urban development.

\section{Commercial development in Ho Chi Minh City and value capture}

As a result of the more stable political situation created by joining the World Trade Organization and the effect of many global companies' "China plus one policy", ${ }^{1}$ Vietnam has now become an attractive place to invest. Hence, the number of high-rise buildings increased in the center of HCMC to supply the demand of office space and hotels from

\footnotetext{
${ }^{1}$ To be less dependent on their investments in Chinese manufacturing industry, many global companies decided to start additional operations in other Asian countries. Vietnam has largely benefitted from this (Bradsher, 2008).
} 
the mid-1990s to 2000s. Whether central areas in Ho Chi Minh City were destined to become "gold land" - as it is referred to in Vietnamese - for the building of high-rises or not depended upon receiving favorable permitting reviews from the relevant local authorities. Currently, there is no set standard for limiting the height of proposed projects, so high-rise buildings in HCMC have been developing according to such personalized permitting procedures, and are generally untethered - or only loosely tethered - to the government's master plan (Son, 2013). This inconsistency has, predictably, resulted in terrible pressures on traffic, drainage and the electrical grid system of the downtown area.

\subsection{A high-rise building trend in mega HCMC}

Before 1975, there were few high-rise buildings in Districts 1 and 5. From 1975 to the end of 1980, the city did not develop any new buildings due to a lack of demand and resulting difficulties securing finance. In the early years of the 1990s, revisions of the Land Law contributed greatly to economic transition by stimulating the private sector in HCMC empowered by FDI in real estate help the city to build new high-rise office buildings in the center area in District 1 (Huynh, 2014; Nguyen et al., 2014). The new wave of constructing commercial and residential high-rise buildings from local and foreign investors physically changed the image of the whole city (Fig. 5).

Since this time, buildings kept rising higher and higher, and structures of 30 to 40 floors became more common. In 2008, Saigon Trade Center (37 Ton Duc Thang st) was the tallest building in the city with 33 floors. In May of 2010, the tallest was the two towers of Saigon Pearl at Nguyen Huu Canh st with 37 floors; by October 2010, it was Financial Tower (Bitexco) with 68 floors, and in July 2014, the city approved the Tan Cang Complex project with 80 floors. High-rise apartment projects are also popping up at the sub-urban fringe in Districts 2, 7 and 9, all of which have well-established local urban infrastructure. From 2009 to 2012, most of the new commercial, residential project applications were high-rise projects either at the sub-urban (such as District 2, Tan Phu and Binh Tan districts) or rural area (such as Hoc Mon, Binh Chanh and Nha Be districts).

The high-rise trend in these recent decades brought positive results for the city. In 2010, the city had around 225 high-rise building projects (Ho Chi Minh City Department of Construction, 2012). In the period between 2008 and 2012, the HCMC Department of Construction approved 104 high-rise projects, among which 41 were located in the central area. Those projects have contributed greatly to the economy of the city, increased land use value, reduced housing prices, and met the demand for office and hotel space. This high-rise wave provided a solution for a broken land redevelopment process, generating new land banks for open space or public use, and upgrading the infrastructure of the city.

\subsection{Problem}

There are some challenges that also arose during this period: development happened outside of the city's control, comprehensive and detailed plans were not ready to accommodate the rapid development of the time, and the real estate market had too strong an influence on the management and development of the city. Since there was a lack of high-rise landscape studies, the haphazard approval of high-rise projects was not required to contribute to any needed additional public infrastructure facilities. The projects that were permitted and crowded in the center, inherited the existing infrastructure, which was often inadequate for the additional density. The locations were chosen based on the interest and capacity of a developer, not on infrastructure feasibility.

More recently, the HCMC Authorities have recognized these limitations and added several measures to solve the problem in high-rise management and development. They developed detailed urban design plans for 930 ha in the central area, Thu Thiem district, and Vo Van Kiet Boulevard. The Department of Architecture and Planning also was empowered with some general principles, guidelines and detailed master plans to develop high-rises in core-urban, new urban and suburban areas depending on population (Kien, 2015). However, it has not yet seen the value being captured to recover the cost of those efforts made to build the infrastructure that has made the new high-rise developments possible. The following case studies illustrate the need for value capture mechanisms to sustainably develop high-rise buildings in HCMC.

\section{Three illustrative case studies}

Each of the following three cases shows how planners and real estate developers can potentially, and in one case have, formally and informally collaborated to resolve the complex aspects of a property rights regime under rapid change conditions. Each reveals a learning process that may eventually become more institutionalized. Case 1 and 2 show problems of missing value capture opportunities, and case 3 presents how capturing the public value in commercial projects has begun to happen.

\subsection{Case study 1: Times Square, District 1}

Currently, Van Thinh Phat Company runs this building. Saigon Times Square began as an FDI (Foreign Direct Investment) project in HCMC's District 1 that had been privately owned before 1975 and served as a famous hotel that had been known as the "Dem Mau Hong" (Pink Night). When the war ended on April 30, 1975, the new communist authority nationalized this property - along with countless

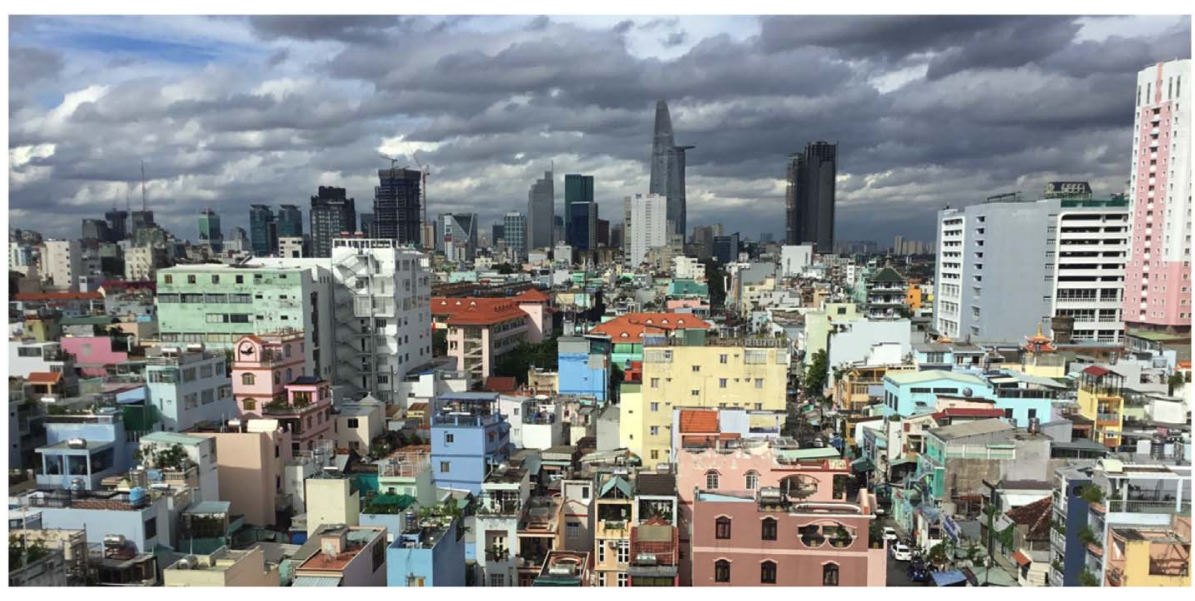

Fig. 5. New high-rise buildings are replacing tube house in District 1. Source: Field Survey, 2016. 


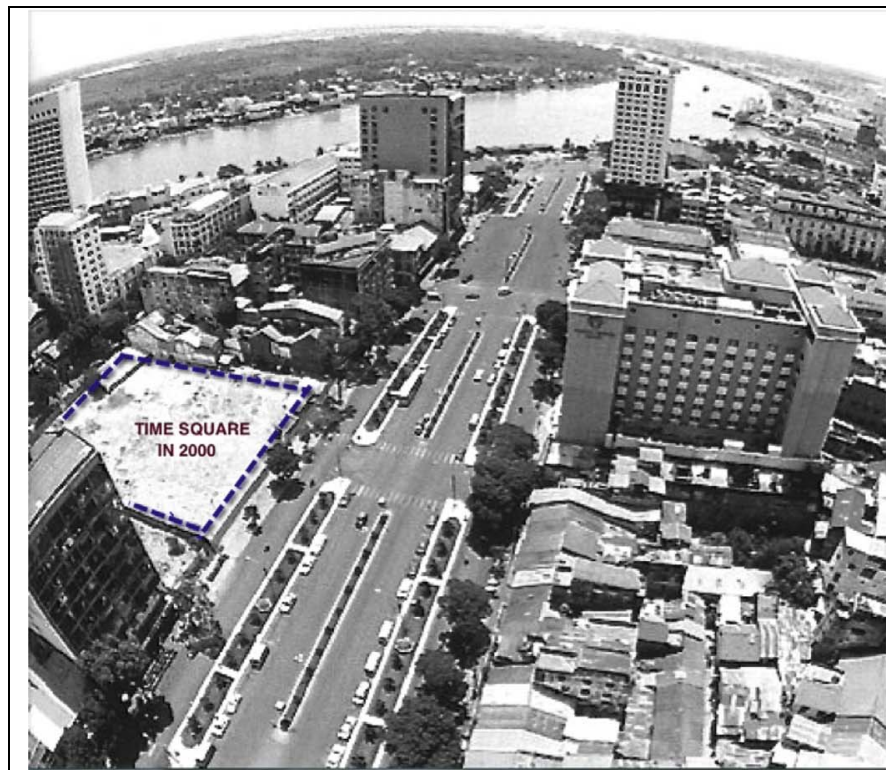

Site clearance in 2000

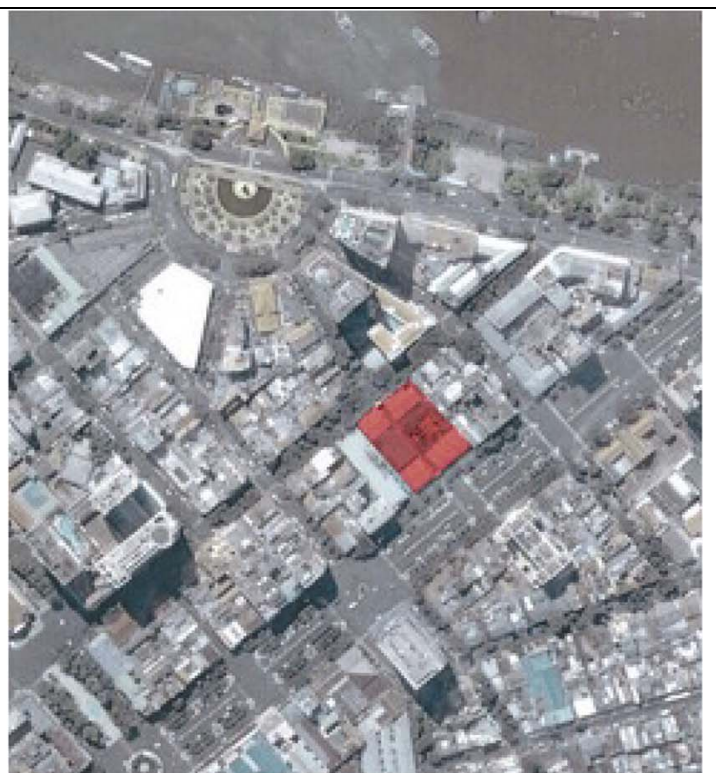

- Status: 35 years land lease from 1995

- Construction: 2005-2012

- Total construction floor: $90000 \mathrm{~m} 2$

- Capital: US\$ 125 mil (year 1999)

- Height: $163.8 \mathrm{~m}, 45$-story tower

- Investor: Times Square Vietnam

Fig. 6. Times Square project profile.

Source: Department of Urban Planning and Architecture, and Google map accessed in 2011.

others throughout the city - and changed it into a public apartment building. In doing so, the city authority transferred land use rights to the Ministry of Light Industry (Southern Office), which used it to house its staff. In 1995, after serving for 20 years in this capacity, the city authorities decided to transform this property into a commercial building complex. The following year, a partnership (Times Square Vietnam) was licensed between Hong Kong's Larkhall Corporation and domestic partners Savico, Pharmaceutical Company No. 2 and Light Industrial Construction Company No. 2. The foreign and domestic partners owned $70 \%$ and $30 \%$, respectively, in land use rights on the 4500-square-meter site (USA International Business Publications, 2008).

This commercial project (See Fig. 6) was projected to cost an estimated US\$ 125 million to build. At that time, 96 households lived in the building and had to be moved to clear the land. Savico took the lead in helping the foreign developers negotiate with each household, and in the end, each apartment $\left(24 \mathrm{~m}^{2}\right)$ was compensated with an average of US\$ 20,000 to move out (source: informal information received from resident). With this amount, each family could afford to buy a small house $\left(50 \mathrm{~m}^{2}\right)$ off an alley, typically found in most suburban districts of Ho Chi Minh City in 1996-1997. This process took about one year to complete, and by 1997 the project was ready for ground breaking and construction.

Upon completion of this phase, the partnership approached the relevant authorities to get necessary approvals to construct a high-rise building (old name was Larkhall Savico Tower) on their piece of landed property. After various administrative procedures, the relevant authorities granted them permission to build a maximum amount of 39 stories.
Unfortunately for the developers, construction was postponed because of the Asian economic crisis in 1997, and the project site was leased out on a temporary basis for building a commercial center to be operated by Kinh Do Corp. and Savico as a "holding" move. After some years being used for this temporary purpose, Time Square Vietnam Company decided in 2007 to collaborate with other local developers, Van Thinh Phat and Saigon Peninsula Company, to improve the financial basis for the project. Total investment cost increased from US $\$ 95$ million to US\$ 125 million. In addition to the change in ownership structure, this sale shifted the project structure from a joint state-private partnership to one that was $100 \%$ Hong Kong private owned - a legal change that had been formalized in the intervening years. At this time of transfer, the project value needed to be appraised based on the location of the land and the number of stories that had been allowed, which was 39. However, after the transaction occurred, the new owner succeeded in negotiating with the local authority to upgrade to a 45story building, under the new name of Times Square.

In addition to this vertical expansion of developable "land", the new developers negotiated other favorable agreements with the local planners. What had been a large retailing area within the project was shifted offsite to adjacent hotels and residential areas, thereby making the new project design even more profitable than the original project. This change allowed a greater number of hotel rooms on the site. The previously required $11,562 \mathrm{~m}^{2}$ of retail space was reduced to $2003 \mathrm{~m}^{2}$, and the previously allowed 231 hotel rooms increased to 285 rooms (see Table 2). From a planning standpoint, this shift in use meant that developers had been allowed to change the function of the project from temporary use to permanent activities in the building. In doing so, it increased the revenue for developers but also put additional pressure on 
Table 2

Application for changing function of the Times Square Project.a

Source: Ho Chi Minh City Department of Urban Planning and Architecture, 2009.

\begin{tabular}{|c|c|c|c|}
\hline \multirow[t]{2}{*}{ Order } & \multirow[t]{2}{*}{ Categories } & \multicolumn{2}{|l|}{ Norm } \\
\hline & & $\begin{array}{l}\text { The approval plan } \\
\text { (Larkhall Savico Tower) }\end{array}$ & $\begin{array}{l}\text { The changed plan } \\
\text { (Time Square) }\end{array}$ \\
\hline 1 & Area & $4.573 \mathrm{~m}^{2}$ & $4.573 \mathrm{~m}^{2}$ \\
\hline 2 & Floor & 39 stories +1 basement +3 technical basements & 45 stories +1 basement +3 technical basements \\
\hline 3 & Height of building ${ }^{\mathrm{a}}$ & $163.8 \mathrm{~m}$ & $163.8 \mathrm{~m}$ \\
\hline 4 & $\begin{array}{l}\text { Building Coverage Ratio } \\
\text { (BCR) }\end{array}$ & $63.9 \%$ & $60 \%$ \\
\hline 5 & Floor Area Ratio (FAR) & 17 & 15.8 \\
\hline 6 & Width of the road & $\begin{array}{l}\text { Đồng Khởi Street: } 20 \mathrm{~m} \\
\text { Nguyễn Huệ Street: } 64 \text { m }\end{array}$ & $\begin{array}{l}\text { Đồng Khởi Street: } 20 \text { m } \\
\text { Nguyễn Huệ Street: } 64 \text { m }\end{array}$ \\
\hline 7 & Distance from the roadside & $\begin{array}{l}\text { Back side of the basement to Đồng Khởi street: } 12.5 \mathrm{~m} \\
\text { Back side of the basement to Nguyễn Huệ street: } 5 \mathrm{~m} \text { South West border: } \\
4.5 \mathrm{~m}-6.4 \mathrm{~m} \text { North East border: } 4 \mathrm{~m}-7 \mathrm{~m}\end{array}$ & $\begin{array}{l}\text { Back side of the basement to Đồng Khởi street: } 5.5 \mathrm{~m} \\
\text { Back side of the basement to Nguyễn Huệ street: } 5 \mathrm{~m} \\
\text { South West border: } 4-7 \mathrm{~m} \\
\text { North East border: } 4.5-6.4 \mathrm{~m}\end{array}$ \\
\hline 8 & Total gross floor area $\left(\mathrm{m}^{2}\right)$ & $84,704 \mathrm{~m}^{2}$ (including technical floor $5161 \mathrm{~m}^{2}$ ) & $\begin{array}{l}90,878 \mathrm{~m}^{2} \text { (including: basement: } 12,294 \mathrm{~m}^{2} \text {, technical floor: } \\
5876 \mathrm{~m}^{2} \text { and roof } 650 \mathrm{~m}^{2} \text { ) }\end{array}$ \\
\hline 9 & Parking & $\begin{array}{l}\text { Basement, from floor } 4 \text { to motorcycle floor 8: } 275 \text { car parking and } 500 \\
\text { motorcycle parking }\end{array}$ & $\begin{array}{l}\text { Ground floor, basement } 1 \text {, basement } 2 \text { and basement 3: } 150 \\
\text { car parking }\end{array}$ \\
\hline 10 & Hotel & 231 rooms from floor 12 to floor 29 of the tower orient to Nguyễn Huệ road & $\begin{array}{l}285 \text { rooms from floor } 12 \text { to floor } 29 \text { of the tower orient to } \\
\text { Nguyễn Huệ road }\end{array}$ \\
\hline 11 & Deluxe apartment for rent & $\begin{array}{l}118 \text { apartments from floor } 12 \text { to floor } 36 \text { of the tower direct to Dong Khoi } \\
\text { and Nguyen Hue street }\end{array}$ & $\begin{array}{l}120 \text { apartments from floor } 12 \text { to floor } 36 \text { of the tower direct } \\
\text { to Dong Khoi Street }\end{array}$ \\
\hline 12 & Restaurant & Floor 38 & Canceled \\
\hline 13 & Top Floor for city View & Floor 39 & On the roof \\
\hline 14 & Helicopter parking & Top & Top \\
\hline 15 & Retail Area & $11.562 \mathrm{~m}^{2}$ & $\begin{array}{l}\text { Reduced to } 2.003 \mathrm{~m}^{2} \text { (the area shifted to hotel and } \\
\text { apartment) }\end{array}$ \\
\hline 16 & Lease & 35 years from 1995 & 45 years from 2005 \\
\hline
\end{tabular}

a The developer reduced the height of each floor from 3.9 to $3.5 \mathrm{~m}$.

the urban infrastructure (electric, water, parking, etc.) without any additional public revenue for upgrading.

The project was completed and opened in December 2014, and the resulting $163.8 \mathrm{~m}$ height project included two 45-stories towers with features of a modern architectural style (See Fig. 7).

The important issue regarding this project's changing parameters was the difference between proposed designs and completed buildings. The discrepancy between the old and new approvals was six stories (see Table 2), which means that it entailed nine thousand square meter difference in GFA. With each square meter in this central business district area valued at greater than US\$ 3300 (1999), the variance from the original permit approximately added over US\$ 27 million to the project's market value, all of which accrued to the developer (minus additional construction costs) without any benefits to the local government that could be used to offset the increased burden on the neighborhood infrastructure. Moreover, the lease period was extended from 35 to 45 years, which adds to the value of the investment as well, also without any additional value captured by the local government. In effect, the result was a transfer of value from the local authorities to the developer, as well as their acceptance of additional unfunded responsibilities for infrastructure and services provision. The real question is whether the construction and realization of the Times Square project

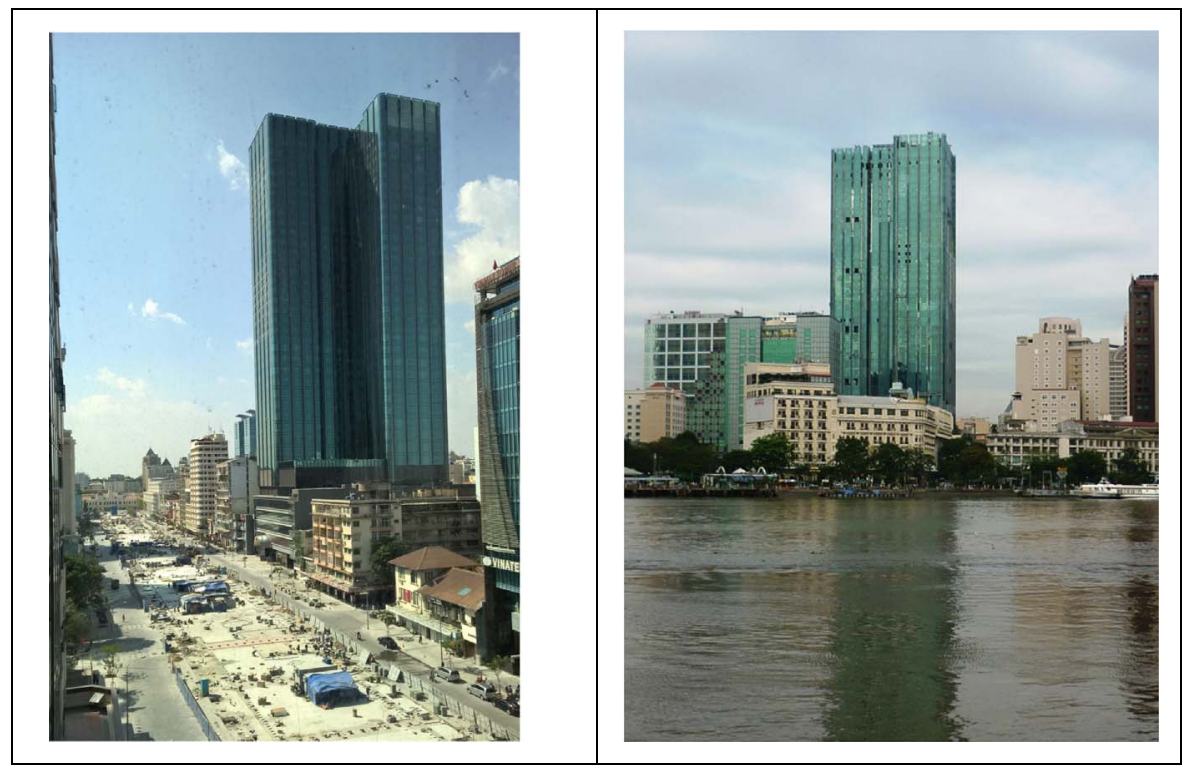

Fig. 7. Times Square is much taller than other buildings in the downtown area.

Source: Field Survey, 2015 


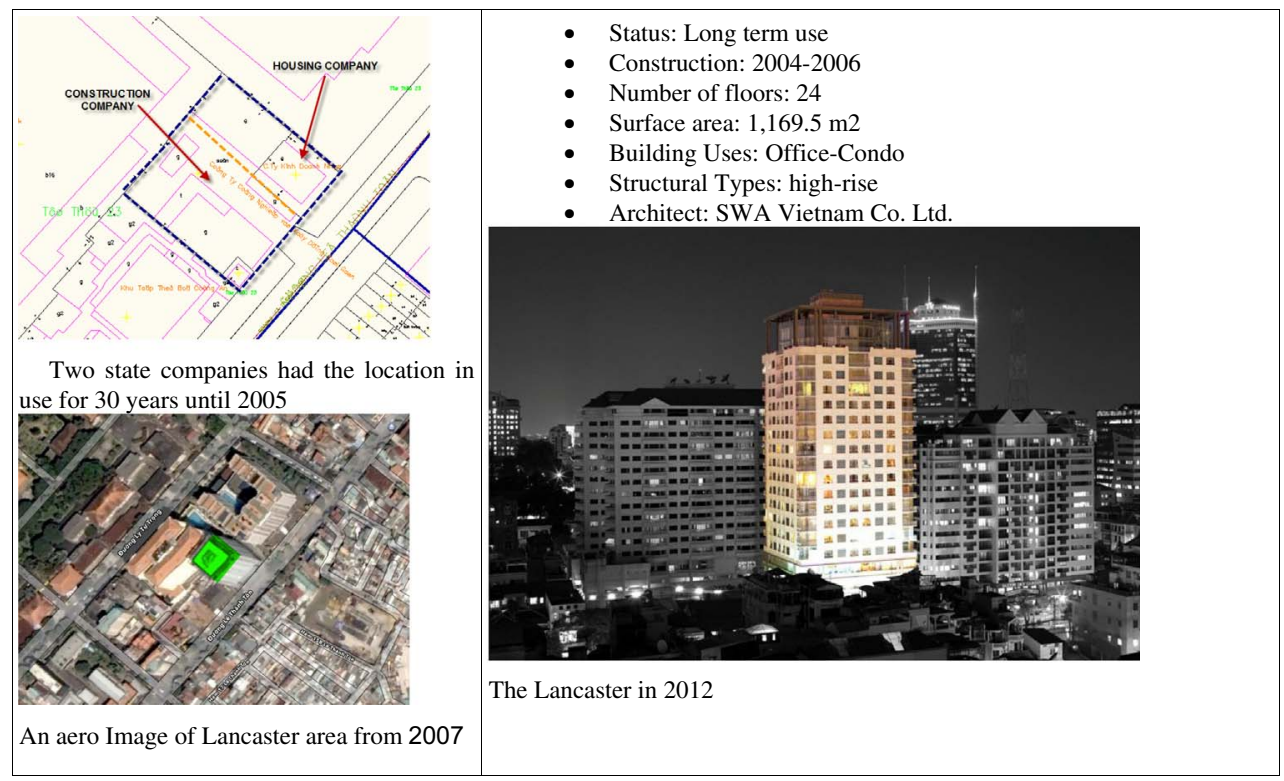

Fig. 8. The Lancaster project profile.

Source: Field survey, Ho Chi Minh City Department of Construction and Apple Maps, 2013. were worth these subsidies and future liabilities.

\subsection{Case study 2: Lancaster, District 1}

Together with the Times Square project, after the war ended in 1975, the HCMC People's Committee (executive arm of the People's Council) occupied a location in downtown HCMC that later became known as The Lancaster (See Fig. 8). Under the old regime, this site of the former Office of the Navy was allocated to two state-owned enterprises: The Saigon Housing Business-Construction Company and Saigon Industry. These new occupants used the site as office space for 30 years. Early in February 2003, however, the HCMC People's Committee decided to take back the land use rights and organized a land auction.

The Ho Chi Minh City Auction of Land Use Rights Council organized the first auction of land No. 22-22 Bis Le Thanh Ton Street, Ben Nghe Ward, District 1 in 2004. At that time, the HCMC People's Committee approved the starting price for this $1169 \mathrm{~m}^{2}$ parcel of land at US\$ 32 million ( 53 billion VND). A private, domestic company won the bidding at the price of US\$ 39 million with a proposed 12-floor project. The winner, Trung Thuy Limited Company, became the new owner under a 40-year lease for the plot, and broke ground for the Lancaster Office Building Project one year later.

Two and a half years later, the Lancaster project was completed and began operating in February 2007. With modern facilities, first-class designs, and a convenient location, the Lancaster building was an excellent residential and working environment. Because of these rare amenities, the developers were able to sell $90 \%$ of the apartments and rent out a similar percentage of the office space by the time the project was complete. Under the 2004 project proposal that had been permitted, the offices and apartments in the building would be sold for US\$ 2000 per square meter, but actually, the real prices in that neighborhood had risen to double that amount by 2007 . The price of the land in the downtown area relied not only on the location but also the "rights of constructing high-rise building" licensed from the authority. However, there was no clear regulation for this. Urban plans did not define how many rights could be obtained in a certain area.

Whereas, at the start of the project the investor was granted a 40-
Table 3

Application for changing of the Lancaster Project.

Source: Ho Chi Minh City Department of Urban Planning and Architecture, 2009.

\begin{tabular}{lll}
\hline Categories & Before & After \\
\hline Status & 40 years & Perpetual lease \\
Function & $\begin{array}{l}\text { Public service, commercial, } \\
\text { hotel and office }\end{array}$ & Condominium, office \\
Construction norm & FAR: 6, BCR: 50\%, stories: 12 & FAR: 9, BCR: 50\%, stories: \\
& & 22
\end{tabular}

year lease period for the land, surprisingly, this 40 year lease had been changed to one with no end date, thereby effectively converting from leasehold to freehold by 2007 (information from apartment owner, September 2013). This was a clear advantage over other apartment buildings in District 1 that only received 49-year ownership leases. Thus, by extending the leasehold duration to an indefinite term roughly equivalent to freehold ownership, the local authorities had effectively increased the value of all apartments in the project exponentially. The developer also raised the height of building from 12 floors to 22 floors (see Table 3). Again, this ad-hoc increased valuation of the project not only created developer profits but also made changes in such a way that the local authorities could not share in that increased valuation.

Beyond the inconsistencies in leases and ownership introduced by this change, the case of The Lancaster also exhibits the importance of arbitrary height variances for the broader issue of value capture. The case study of The Lancaster project on Le Thanh Ton Street showed that this site could make twenty-two floors, while it initially only held permission for twelve floors, and two slots next to it were allowed only ten floors. This height constraint was also a common fact in other streets in the Central Business District, and there was no clear criteria making decisions on permitting variances on the height of a project. The city also recognized this limitation, and HCMC authority decided to introduce more detailed master plans - down to the $1 / 2000$ scale - for the entire Central Business District (CBD) area in 2013 (Sơn, 2014). 


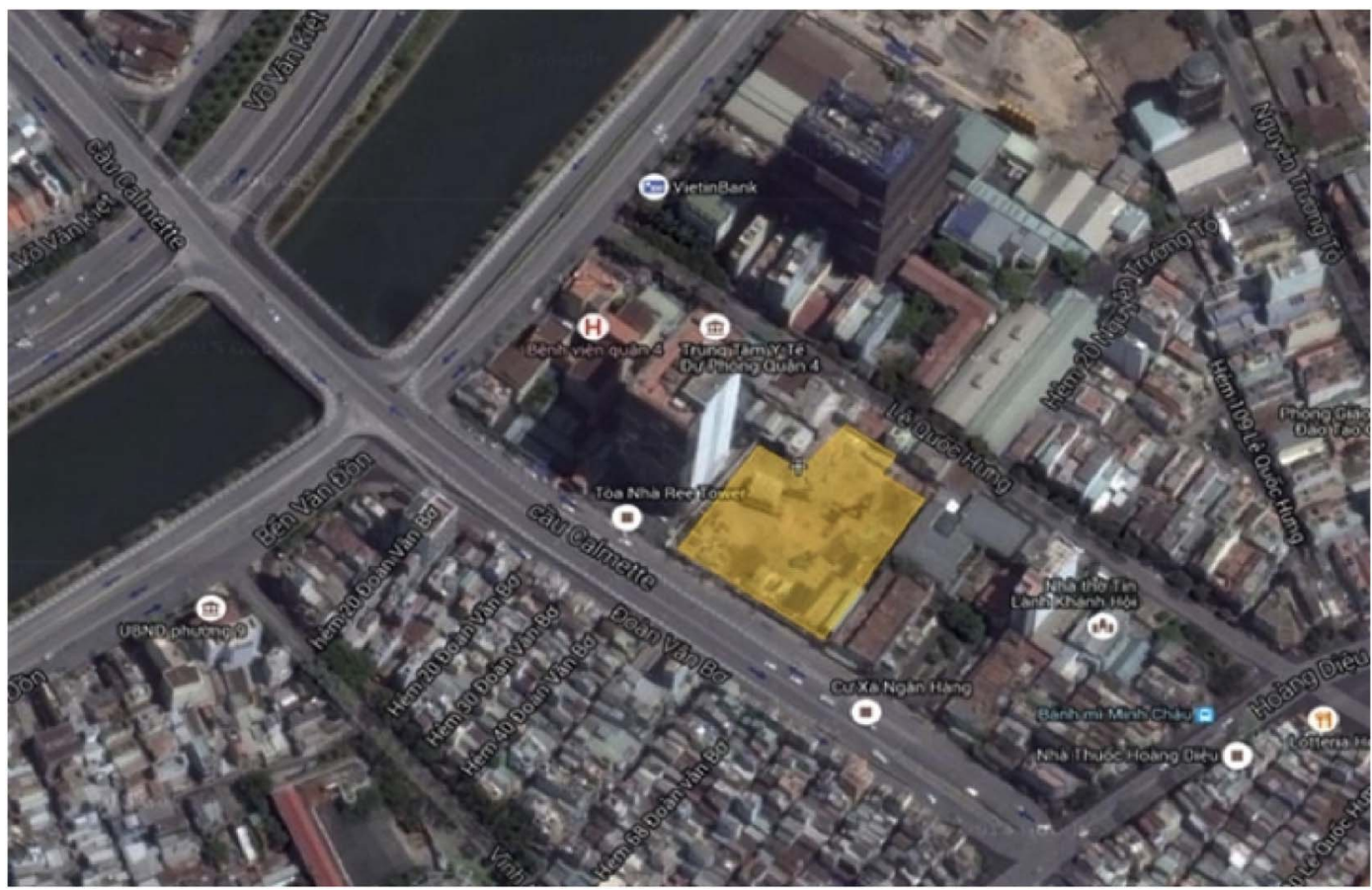

Fig. 9. Land location of REE Tower 2: 11 Doan Van Bo St, District 4.

Source: Google Map, 2014.

\subsection{Case study 3-REE Tower 2 Project, District 4: applied value capturing}

The previous two case studies described the effects of an apparent high level of confusion among the city authorities on how to decide the value of a construction project, particularly as the policy and regulations change mid-way through project implementation. In large part a response to these challenges, the city established a new system to handle this issue of project valuation.

Decision 6708/QD-UBNN on 29/12/2012 is the first critical Zoning Plan for the 930 ha of the Center Area (See Fig. 1), and our third case study illustrates how projects are now treated. In sum, this first-ever zoning plan states clearly how much the developer could develop in terms of height, coefficient and buffering from the road.

REE Tower 2 is located in District 4, inside the 930 ha center zoning (See Fig. 9). Originally, the City owned the Friendship trading-industrial Joint Stock Company (FRIENDCO), and used the $5503 \mathrm{~m}^{2}$ site primarily as storage space. In 2009, the HCMC PC decided to prohibit the storage function because it was polluting the neighborhood, and eventually transferred it to the Open University for use as a temporary branch campus through 2013.

Still owned by FRIENDCO, the land became a joint-venture commercial development agreement in 2013 with the Refrigeration Electrical Engineering Corporation (REE Corp). REE Corp invests $\$ 54,5$ million, including $\$ 13,6$ million of total construction investment, and $\$ 40,9$ million for land use rights of 50 years to develop a high-rise commercial building. The joint-venture created the Song Mai Company

Table 4

Land use information of project.

Source: DPA, 2015.

\begin{tabular}{ll}
\hline Function & Area $\left(\mathrm{m}^{2}\right)$ \\
\hline Office and commercial building & 1764.9 \\
Public park & 527 \\
Public open space & 1406.3 \\
Internal transportation & 890 \\
Total & 4588 \\
\hline
\end{tabular}

to run the project, including securing the land from the City at a market price, and under the condition that they must break ground for the building within a year after the land use rights were granted.

Song Mai plans to have a complete A office building (luxury), REE Tower 2 by 2017, on a total land area of $4588 \mathrm{~m}^{2}$, with a total floor space of $66,000 \mathrm{~m}^{2}$ on 27 floors (See Table 4). The developer wants to have $35,000 \mathrm{~m}^{2}$ rentable area with underground five levels of parking $\left(16,000 \mathrm{~m}^{2}\right)$.

Prior to the current plans, FRIENDCO called for investment in this project in 2005. The Global company (a local real estate developer) was interested at that time in this land. Both sides had an initial agreement to develop the project. Decree 11/HN/TCKT formed a joint venture among three companies: The Global Company - 65\% (by capital), FRIENDCO - 20\% and Saigon Industry Corporation (CNS) - 15\% (by land). The Global Company was responsible for the investment procedure, and in doing so they were able to change the storage function to commercial use by influencing the regulators on land use rights. Two years later, FRIENDCO decided to terminate its partnership with The Global Company, thereby making this arrangement moot. After several years resolving these partnership problems, REE Land stepped in as a substitute for the Global Company as a new partner to continue the project in 2014.

However, immediately after securing the investment certificate, the developer found that the proposal construction amount would not be profitable enough for them to process investment. They proposed some changes according to Article 6 of the regulation, suggesting that if the developer could contribute to the city community, they would get a higher land use coefficient based on their contribution. By law, the Department of Urban Planning and Architecture (DUPA) could discuss with the developer about their reasonable extension publicly, which is still in the range of the 930 ha City Center Plan.

The Department of Urban Planning and Architecture approved the developer's original construction plan that allowed for 27 floors and a total of 100 -meter height, one block, $40 \%$ land coverage, and setbacks 


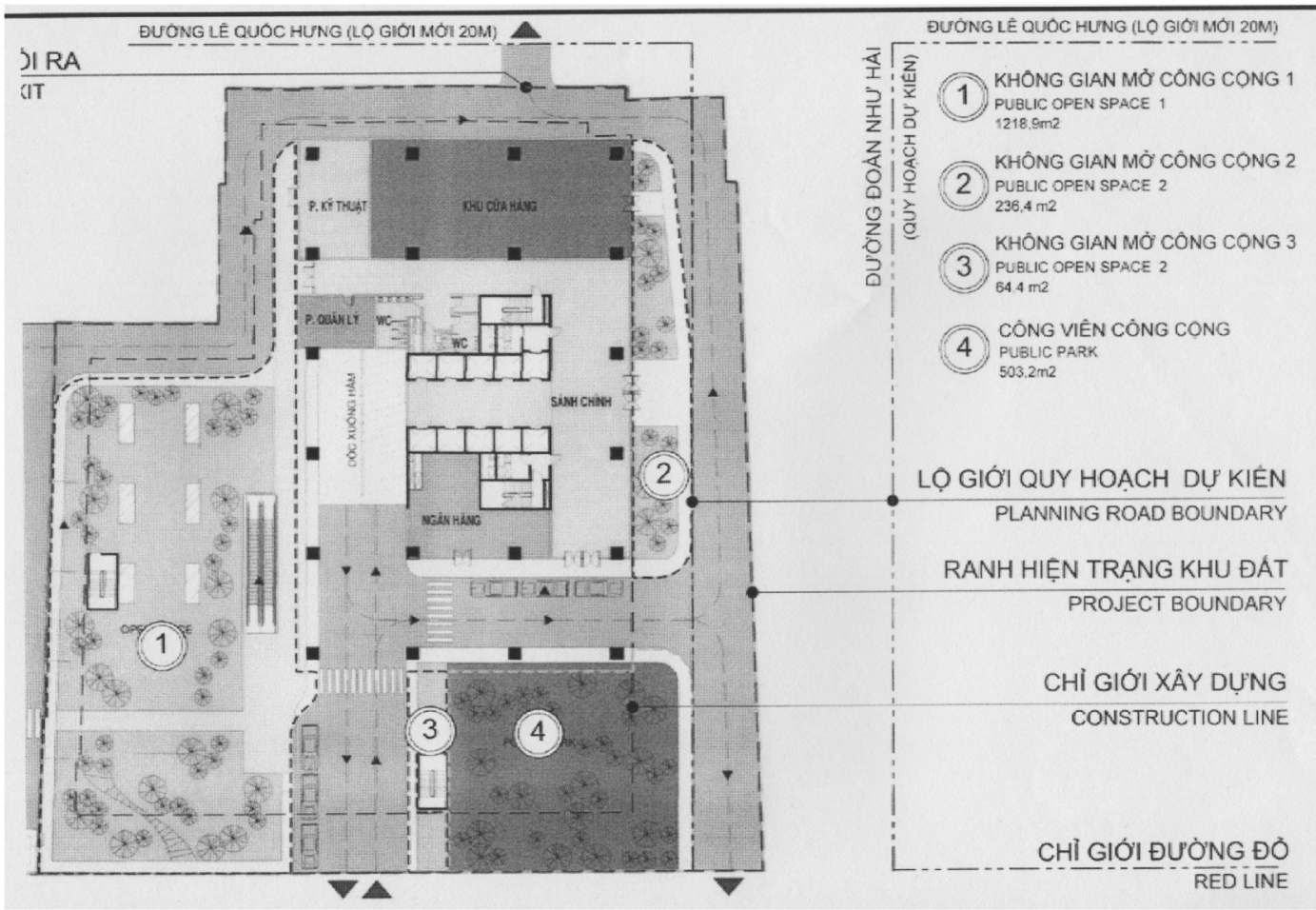

Fig. 10. Master Plan of REE 2 (case three) - with a park preserved for public use (\#4).

Table 5

Coefficient changes.

Source: Ho Chi Minh City Department of Urban Planning and Architecture, 2015.

\begin{tabular}{lc}
\hline Reasons & Bonus \\
\hline Friendly environmental plan & +1 \\
Suitable parcel and land sharp & +1 \\
Land close to the big road ( $>30$ m wide) & +1 \\
Add a green space in project & +0.5 \\
Preserve 30\% of land for public-use park & +1 \\
Make a segment of Doan Nhu Hai road & +0.5 \\
Total & +5 \\
\hline
\end{tabular}

between $6 \mathrm{~m}$ and $20 \mathrm{~m}$, depending on the street façade (Fig. 10).

Under this plan, DUPA allowed a land use coefficient of only 5. To make the project profitable, however, FRIENCO asked for a higher coefficient ratio if they financially contributed to the public road across the project in the short term, and let the public access the open space on their two projects for the longer term (see Fig. 10). The City Urban Planning Committee approved the request for a new land use coefficient of 10 , thereby making the project profitable for the developer, while at the same time contributing to the road and open space infrastructure of the neighborhood (Decision \#547/SQHKT-QHKTT). DUPA calculated the new coefficient based on the following scores in the Table 5.

This case shows that the city authorities have begun to apply economic instruments to urban management. For the first time, the developer proposed value capturing in advance instead of being forced to do so. In the past, the city authority had regulatory authority to require the developer to provide green space for the public, or suitable height according to zoning laws, but usually the developers did not follow them, seeing only restrictions on their profitability. Thus, under this new model, DUPA can achieve its planning goals by making appropriate value-adding adjustments to projects in a more collaborative manner. If the municipality is able to multiply this value capturing model to other projects, the city manager stands to gain much more green (open) space for the whole center area as well as for the entire city, than under the old regulatory practices (Fig. 11).

\section{Discussion}

We found substantial changes between proposed designs and

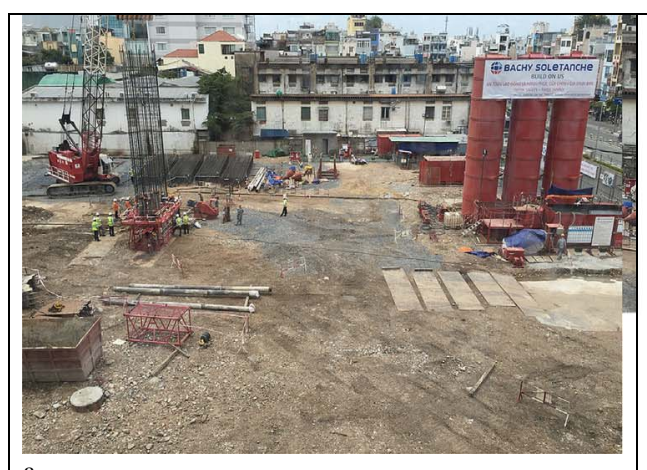

a.

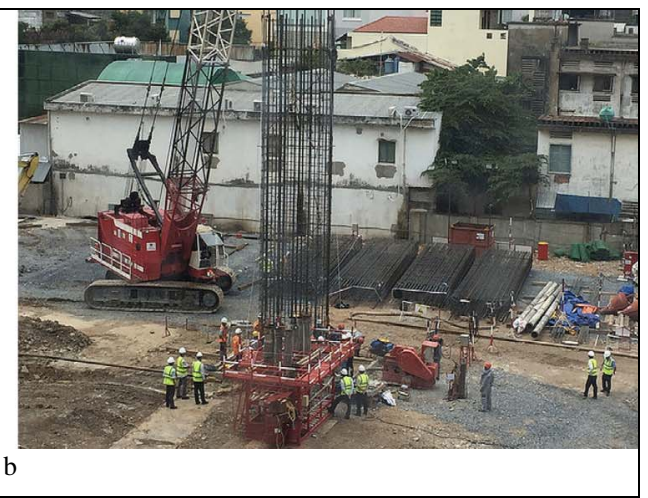

Fig. 11. REE 2 Tower is under construction and will be completed in 2018 .

Source: http://www.skyscrapercity.com/. 
completed constructions with regard to three high-rise projects in HCMC. The cases of Times Square, The Lancaster, and REE Tower suggest that the ad-hoc, not-institutionalized nature of permitting development in HCMC provides numerous opportunities for developers to strategically negotiate with individuals in local government in an environment of policy ambiguity. These ambiguities related to retail/residential mix, height variances, and ownership duration terms have all marked missed opportunities for local authorities and their constituencies to share in increased project values.

This lack of a set of guidelines allowed the developers to take advantage of the local authorities at what may be the expense of the neighborhood communities. While a strict legal environment for value capture may be a valid long-term objective, the rapid rate of growth and development in urban areas suggest that this will take a long time to develop. In the interim, however, it does appear that the problem of institutional structure might - in the short- and medium-term - be addressed by increasing the capacities and technical assistance resources of local authorities. Each of these projects was constructed on land that was openly auctioned in Ho Chi Minh City, a ground-breaking practice at the time, and therefore the subject of much public and private scrutiny. In general, the case of Times Square suggests that project transfers and post-permitting negotiations are common problems that might be systematically addressed through policies more accommodating of long-term valuation and the permitting process. The case of The Lancaster illustrates how the context of Vietnam's particular land ownership laws can create value that is often not captured by state entities through the variance of ownership duration terms. Finally, the case of 3 REE shows that some collaborative and creative joint microscale planning between local authorities and developers can result in adequate capture of value to the public through private infrastructure investments.

Alexander (2012) argues that institutional design is critical for effective value capture. Rationalizing public and private land value capture achieves a number of important objectives. First, regional economic stabilization and fiscal decentralization allow local municipalities to be flexible in management to deal with developers, and encourages them to contribute to city revenues, thereby making local authorities less dependent on funding from the central government, and weaning local authorities away from the unsustainable practice of land sales to cover recurring public expenditures (He, Zhou, \& Huang, 2016). Secondly, more progressive strategies for urban planning and management avoid planning by blue print, encourage private market actors to cooperate with other public and private entities, and decide what they would like to develop. Thirdly, rationalizing value capture encourages clearer property rights, increases social awareness, and supports a more equitable distribution of benefits. To achieve this flexibility, market cooperation, and transparency, value capture rationalization must conform to the broader processes of changing attitudes toward privatization and public-private partnerships in Vietnam, whereby private developers are recognized as partners, not as actors to control.

\section{Conclusions and recommendation}

Transformations comprise forming institutions, laws, regulations, plans and actions (Alnsour, 2016). In Ho Chi Minh City, the emergence and development of high-rise buildings have been driven by broad policy shifts to the privatization of property rights. Substantial flexibility in plan implementation provides the conditions for private developers to be unofficially acknowledged by state planners as a complementary set of institutions in land and property development. This flexibility is also an explanation for why many city plans are often adjusted significantly once they move from plan to implementation. By allowing for such variances, yielding, and delegating decision-making autonomy to individual developers, the state has established private developers as major stakeholders in redevelopment and assigned them the status of co-partners in development at the local level. What they are currently learning now is how to capture value for the public as these variances are allocated. While this model dominates many municipal planning and development processes in the United States and Europe, this kind of urban public-private-partnership in Vietnam is new territory in urban governance, and operates without significant controls and incentives mitigating pure developer interests. In Vietnam, the development of this kind of public-private-partnership for urban management was enabled by ambiguous policy reforms and general plans that focused on macro issues rather than development projects. The case studies in this paper provide narratives of the impact of this ambiguity on the micro level, and it is through the negotiation of these kinds of projects that institutional models will become more formal.

McCluskey and Trinh (2013) argue that other, more structural land based revenue sources, including property and land tax, are at present unsustainable in Vietnam, lack buoyancy and represent a declining revenue base. Property tax reform is needed to improve the income base of Vietnamese cities, in the perspective of future demand for all kinds of new infrastructure. Moreover, effective tools are still missing to capture part of the value increase that appeared as a result of adaptations to the original plan. Without these tools, with negotiations taking place on a case-by-case basis and with insufficient transparency in the negotiation processes, planners are in a weak position. With the privatization of land use rights and housing ownership in the open policy, Vietnam is applying market economy mechanisms in restructuring land management to encourage investment. It has yet to be seen whether this reform will result in a better designed and better functioning downtown built environment.

The issue is not one of ownership per se but the manner in which the relations between market, state and civil society are resolved over time. While in China and post-socialist cities in the Eastern European countries the move to private property rights seems to lead to sprawl, the Vietnamese example is the opposite, where developers are not only building in the core but trying hard to build higher and higher, which is a mark of the so-called compact city. Value capture mechanisms make for better coordination between land use planners and investor interest in spatial planning. New, policy-oriented thinking on the details of exactions and charges for building rights will be an increasingly useful tool in urban growth management and land-based finance for urban development. With such mechanisms in place, eventually private developers will need to balance their plans with city interests better, and this practice has already begun to take root.

More broadly, the case studies presented here contribute to a sorely needed body of research on how planners and real estate developers collaboratively negotiate and align interests to enable the very complex built projects that facilitate urbanization across rapidly developing regions.

\section{Acknowledgements}

The authors would like to thank community members and experts who kindly contributed their time to discuss these projects with us, and we hope they will ultimately be the beneficiaries of any policy reforms related to value capture. The research is partially supported by the Ho Chi Minh City Open University (Project No. E2016.7.7.1). Any mistakes or errors, of course, are the authors' alone. 
Appendix A. Property rights in Vietnam Land Law 2013

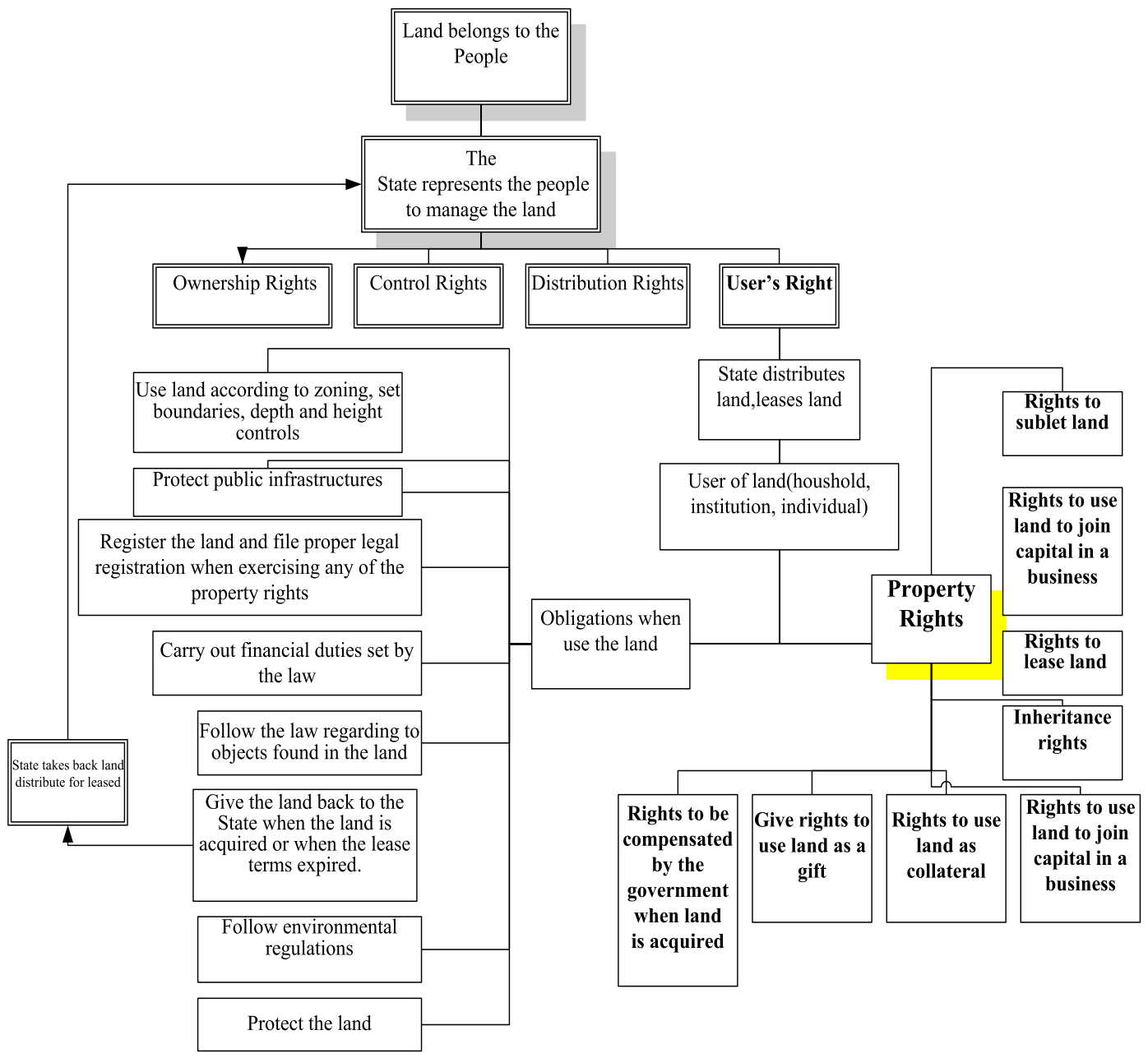

Source: Han and Vu (2008).

\section{References}

Alexander, E. R. (2012). Institutional design for value capture and a case: The Tel-Aviv Metropolitan Park. International Planning Studies, 17(2), 163-177. http://dx.doi.org/ 10.1080/13563475.2012.673738.

Alnsour, J. A. (2016). Managing urban growth in the city of Amman, Jordan. Cities, 50, 93-99. http://dx.doi.org/10.1016/j.cities.2015.08.011.

Alterman, R. (2011). Land-use regulations and property values: The "windfalls capture" idea revisited. In N. Brooks, K. Donaghy, \& G.-J. Knaap (Eds.), The Oxford handbook of urban economics and planning (pp. 755-786). Oxford University Press.

Bradsher, K. (2008). Investors Seek Asian Options to Costly China. New York Times. Retrieved from http://www.latrobefinancialmanagement.com/Academic/SBHAcadamy/Articles\%20and\%20Research/Investors\%20Seek\%20Asian\%200ptions $\% 20$ to $\% 20$ Costly $\% 20$ China.pdf.

Calavita, N., \& Mallach, A. (2009). Inclusionary housing, incentives, and land value recapture. (Retrieved from).

Cervero, R. (1994). Rail transit and joint development: Land market impacts in Washington, D.C. and Atlanta. Journal of the American Planning Association, 60(1), 83-94. http://dx.doi.org/10.1080/01944369408975554.

Dapice, D., Perkins, D., Thanh, N. X., Anh, V. T. T., Du, H. T., Pincus, J., \& Saich, T. (2009). Choosing success: The lessons of East and Southeast Asia and Vietnam's future. A policy framework for Vietnam's socioeconomic development, 2011-2020. Vietnam.

Darosa, M. (2007). When are affordable housing exactions and unconstittutional talking? Willammetter Law Review, 43(3).

Ding, C. (2007). Policy and praxis of land acquisition in China. Land Use Policy, 24(1), 1-13. http://dx.doi.org/10.1016/j.landusepol.2005.09.002.

Ding, C. (2013). Building height restrictions,land development and economic costs. Land Use Policy, 30(1), 485-495. http://dx.doi.org/10.1016/j.landusepol.2012.04.016.

Evans-Cowley, J. S. (2008). Impact fees and exactions. In T. U. Planning (Ed.), Texas planning guide (Texas).
Feder, G., \& Feeny, D. (1991). Land tenure and property rights: Theory and implications for development policy. World Bank Economic Review, 5(1), 135-153.

Fforde, A. (2010). Rethinking the political economy of conservative transition: The case of Vietnam. Journal of Communist Studies \& Transition Politics, 26(1), 126-146. http:// dx.doi.org/10.1080/13523270903511855.

Gerber, J.-D., Nahrath, S., \& Hartmann, T. (2017). The strategic use of time-limited property rights in land-use planning: Evidence from Switzerland. Environment and Planning A, O(0), 0308518X17701916. http://dx.doi.org/10.1177/ 0308518 X17701916.

Gillespiet, J. (1998). Land law subsystems? Urban Vietnam as a case study. Pacific Rim Law \& Policy Association, 7(3).

Han, S. S., \& Vu, K. T. (2008). Land acquisition in transitional Hanoi, Vietnam. Urban Studies, 45(5-6), 1097-1117. http://dx.doi.org/10.1177/0042098008089855.

Hare, D. (2008). The origins and influence of land property rights in Vietnam. Development Policy Review, 26(3), 339-363. http://dx.doi.org/10.1111/j.1467-7679. 2008.00413.x.

He, C., Zhou, Y., \& Huang, Z. (2016). Fiscal decentralization, political centralization, and land urbanization in China. Urban Geography, 37(3), 436-457. http://dx.doi.org/10. 1080/02723638.2015.1063242.

Ho, P. (2017). Who owns China's housing? Endogeneity as a lens to understand ambiguities of urban and rural property. Cities, 65, 66-77. http://dx.doi.org/10.1016/j. cities.2017.02.004.

Ho Chi Minh City Department of Urban Planning and Architecture (2009). Time Square: Final Project Proposal. Ho Chi Minh City, Vietnam.

Ho Chi Minh City Department of Planning and Architecture (DPA), 2011

Ho Chi Minh City Department of Construction (2012). List of tall buildings in Ho Chi Minh City.

Ho Chi Minh City Department of Urban Planning and Architecture (2015). REE Tower 2: Final Project Proposal. Ho Chi Minh City, Vietnam.

Huong, L. T. T., \& Sajor, E. E. (2010). Privatization, democratic reforms, and microgovernance change in a transition economy: Condominium homeowner associations 
in Ho Chi Minh City, Vietnam. Cities, 27(1), 20-30. http://dx.doi.org/10.1016/j. cities.2009.11.007.

Huxley, J. (2009). Value capture finance making urban development pay its way. Retrieved from http://uli.org/wp-content/uploads/ULI-Documents/Value-CaptureFinance-Report.pdf.

Huynh, D. (2014). The effects of clustering on office rents: Empirical evidence from the rental office market in Ho Chi Minh City. Theoretical and Empirical Researches in Urban Management, 9(1), 5-26.

Huynh, D. (2015). The misuse of urban planning in Ho Chi Minh City. Habitat International, 48(0), 11-19. http://dx.doi.org/10.1016/j.habitatint.2015.03.007.

Kien, T. T. (2015). Phat Trien Cong Trinh Cao Tang Tai Thanh Pho Ho Chi Minh-Xu The Cua Do Thi. Paper presented at the 40 Quy Hoach \& Kien Truc Thanh Pho Ho Chi Minh: Thanh Tuu, Kinh Nghiem, Van De, and Giai Phap, Ho Chi Minh.

Kim, A. (2004). A market without the "right" property rights. The Economics of Transition, 12(2), 275-305. http://dx.doi.org/10.1111/j.0967-0750.2004.00179.x.

Labbé, D., \& Musil, C. (2014). Periurban land redevelopment in Vietnam under market socialism. Urban Studies, 51(6), 1146-1161. http://dx.doi.org/10.1177/ 0042098013495574.

Lai, Y., Peng, Y., Li, B., \& Lin, Y. (2014). Industrial land development in urban villages in China: A property rights perspective. Habitat International, 41(0), 185-194. http://dx. doi.org/10.1016/j.habitatint.2013.08.004.

McCluskey, W. J., \& Trinh, H.-L. (2013). Property tax reform in Vietnam: Options, direction and evaluation. Land Use Policy, 30(1), 276-285. http://dx.doi.org/10.1016/ j.landusepol.2012.03.007.

McPherson, M. F. (2012). Land policy in Vietnam: Challenges and prospects for constructive change. Journal of Macromarketing. http://dx.doi.org/10.1177/ 0276146711427447.

Nguyen, T. B., van der Krabben, E., \& Samsura, D. A. A. (2014). Commercial real estate investment in Ho Chi Minh City - A level playing field for foreign and domestic investors? Habitat International, 44(0), 412-421. http://dx.doi.org/10.1016/j. habitatint.2014.08.002.

Nguyen, T. B., Van der Krabben, E., \& Samsura, D. A. A. (2016). A curious case of property privatization: Two examples of the tragedy of the anticommons in Ho Chi Minh CityVietnam. International Journal of Urban Sciences, 1-19. http://dx.doi.org/10.1080/ 12265934.2016.1209122.

Perkins, D. H. (2009). China's land system: Past, present, and future. Cambridge: Paper presented at the Property Rights and Land Policies.

Phe, H. H. (2002). Investment in residential property: Taxonomy of home improvers in Central Hanoi. Habitat International, 26, 471-486.

Quang, N., \& Kammeier, H. D. (2002). Changes in the political economy of Vietnam and their impacts on the built environment of Hanoi. Cities, 19(6), 373-388. http://dx. doi.org/10.1016/s0264-2751(02)00068-9.

Rodríguez-Bachiller, A., Thomas, M., \& Walker, S. (1992). The English planning lottery: Some insights from a more regulated system. Town Planning Review, 63(4), 387. http://dx.doi.org/10.3828/tpr.63.4.w03mu042w170km56.

Scarpaci, J. L. (2000). On the transformation of socialist cities. Urban Geography, 21(8), 659-669. http://dx.doi.org/10.2747/0272-3638.21.8.659.

Shan, L., Yu, A. T. W., \& Wu, Y. (2017). Strategies for risk management in urban-rural conflict: Two case studies of land acquisition in urbanising China. Habitat International, 59, 90-100. http://dx.doi.org/10.1016/j.habitatint.2016.11.009.

Sharan, D. (2016). Value capture for better infrastructure. Retrieved from https://www. adb.org/news/op-ed/value-capture-better-infrastructure-diwesh-sharan.

Smith, J. J., \& Gihring, T. A. (2006). Financing transit systems through value capture: An annotated bibliography. American Journal of Economics and Sociology, 65(3), 751-786. http://dx.doi.org/10.2307/27739588.

Smolka, M. O. (2013a). Implementing value capture in Latin America: Policies and tools for urban development. Lincoln Institute of Land Policy.
Smolka, M. O. (2013b). Implementing value capture in Latin America: Policies and tools for urban development. Retrieved from https://www.lincolninst.edu/pubs/dl/2244 1581_Implementing_Value_Capture_in_Latin_America.pdf.

Smolka, M. O., \& Amborski, D. (2000). Value capture for urban development: An InterAmerican comparison. Retrieved from https://www.lincolninst.edu/pubs/dl/1279 Smolka\%20Final.pdf.

Sơn, Đ. (2014). Công bố đồ án quy hoạch chi tiết $1 / 2.000$ khu trung tâm TP.HCM. Thanh Niên Online. Retrieved from http://www.thanhnien.com.vn/pages/20140116/congbo-do-an-quy-hoach-chi-tiet-1-2-000-khu-trung-tam-tp-hcm.aspx.

Son, N. V. N. (2013). City center planning: Ho Chi Minh City and Hanoi. Vietnam Architecture Magazine, 1 \& 2

Sun, L., \& Liu, Z. (2016). Illegal but rational: Why small property rights housing is big in China. (Retrieved from).

Tan, D. P. (2010). Transformation of socio-economic structure and urban form under doi-moi policy and globalization process, Ho Chi Minh City, Vietnam (PhD Doctoral)Japan: Meijo University.

Temelová, J., \& Dvořáková, N. (2012). Residential satisfaction of elderly in the city centre: The case of revitalizing neighbourhoods in Prague. Cities, 29(5), 310-317. http://dx.doi.org/10.1016/j.cities.2011.11.015.

Thien Thu, T., \& Perera, R. (2011). Consequences of the two-price system for land in the land and housing market in Ho Chi Minh City, Vietnam. Habitat International, 35(1), 30-39. http://dx.doi.org/10.1016/j.habitatint.2010.03.005.

Tira, M., Van der Krabben, E., \& Zanon, B. (2011). Land management for urban dynamics. Innovative methods and practices in a changing Europe. Maggioli Editore.

UN-Habitat (2015). Municipal financing in developing cities: Review of land-based finance training package for financing sustainable urban development. (Retrieved from).

United Nations (1976). The Vancouver action plan. D. Land. Paper presented at the United Nations Conference on Human Settlements Vancouver, Canada.

USA International Business Publications, U. I. U (2008). Vietnam investment projects and joint ventures handbook. IBP USA, USA International Business Publications.

Van der Krabben, E., \& Needham, B. (2008). Land readjustment for value capturing. TPR: Town Planning Review, 79(6), 651-672.

Vinh, N. Q., \& Leaf, M. (1996). City life in the village of ghosts: A case study of popular housing in Ho Chi Minh City, Vietnam. Habitat International, 20(2), 175-190. http:// dx.doi.org/10.1016/0197-3975(95)00048-8.

Waibel, M., Eckert, R., Bose, M., \& Martin, V. (2007). Housing for low-income groups in Ho Chi Minh City between re-integration and fragmentation. ASIEN, 103, 59-78.

Walters, L. C. (2012). Land value capture in policy and practice. Paper presented at the The Annual World Bank Conference on Land and Poverty, Washington, D.Chttp://www. landandpoverty.com/.

World Bank (2015a). Annual World Bank Conference on Land and Poverty 2015: Linking land tenure and use for shared prosperity. DC: Washington.

World Bank (2015b). Vietnam affordable housing : A way forward. Washington, DC: World Bank.

Xuan, L. R., Low, A., \& Chua, S. (2012). A study of urban planning and management: Case study on Ho Chi Minh City. 9th OAPS Working Paper SeriesHongkong: City University of Hong Kong. Retrieved from http://hdl.handle.net/123456789/217.

Zeković, S., Vujošević, M., \& Maričić, T. (2015). Spatial regularization, planning instruments and urban land market in a post-socialist society: The case of Belgrade. Habitat International, 48, 65-78. http://dx.doi.org/10.1016/j.habitatint.2015.03.010.

Zheng, H., Wang, X., \& Cao, S. (2014). The land finance model jeopardizes China's sustainable development. Habitat International, 44(0), 130-136. http://dx.doi.org/10. 1016/j.habitatint.2014.05.008.

Zhu, J. (2011). Development of sustainable urban forms for high-density low-income Asian countries: The case of Vietnam: The institutional hindrance of the commons and anticommons. Cities, (0), 517-526. http://dx.doi.org/10.1016/j.cities.2011.08. 005 . 